\title{
eCommons@AKU
}

Department of Paediatrics and Child Health

Division of Woman and Child Health

July 2014

\section{Should research fraud be a crime?}

Zulfiqar Ahmed Bhutta

Aga Khan University, zulfiqar.bhutta@aku.edu

Julian Crane

University of Otago Wellington

Follow this and additional works at: http://ecommons.aku.edu/

pakistan_fhs_mc_women_childhealth_paediatr

Part of the Community-Based Research Commons, and the Social Control, Law, Crime, and Deviance Commons

\section{Recommended Citation}

Bhutta, Z. A., Crane, J. (2014). Should research fraud be a crime?. BMJ, 349.

Available at: http://ecommons.aku.edu/pakistan_fhs_mc_women_childhealth_paediatr/193 


\title{
HEAD TO HEAD
}

\section{Should research fraud be a crime?}

Zulfiqar A Bhutta says that criminal sanctions are necessary to deter growing deliberate research misconduct, which can ultimately harm patients. Julian Crane disagrees: he doubts that sanctions will have any deterrent effect and worries that criminalisation would undermine trust

\author{
Zulfiqar A Bhutta Robert Harding chair in global child health and policy ${ }^{1}$, Julian Crane director ${ }^{2}$ \\ ${ }^{1}$ Center for Global Child Health, Hospital for Sick Children, Toronto, Canada; ${ }^{2}$ Wellington Asthma Research Group, Department of Medicine, \\ University of Otago Wellington, PO Box 7343, Wellington 6242, New Zealand
}

\section{Yes-Zulfiqar A Bhutta}

The fact that research fraud is common and possibly on the rise globally isn't news any more. A review of all 2047 retracted biomedical research articles indexed by PubMed up to 3 May 2012 found that $67.4 \%$ of retractions were attributable to scientific misconduct, including fraud or suspected fraud (43.4\%), duplicate publication $(14.2 \%)$, and plagiarism $(9.8 \%){ }^{1}$ Other assessments indicate that the number of articles retracted a year increased 19-fold from 2001 to 2010, and the increase was still 11-fold after repeat offenders were excluded and growth of the literature had been adjusted for. ${ }^{2}$

The typology of research malfeasance varies, from sloppy research to outright deliberate fraud. Most serious research fraud relates to fabrication, falsification, and plagiarism. ${ }^{3}$ Estimates of prevalence may yet be conservative. In a meta-analysis of survey data, Fanelli suggested that $2 \%$ of all scientists admitted to falsifying, fabricating, or modifying data at least once. ${ }^{4}$ The scale of research fraud ranges from individual high profile cases, such as in recent stem cell research from Korea and Japan, ${ }^{56}$ to documented fraud by the drug industry, such as suppression of paroxetine safety data by GlaxoSmithKline. ${ }^{7}$ This last case included selective reporting or non-disclosure of critical information on safety as well as falsification of data. Similar charges were proved against the Indian generics manufacturer Ranbaxy, which was subsequently fined $\$ 500 \mathrm{~m}$ (£290m; $€ 370 \mathrm{~m}$ ) for data falsification after its global head of research and portfolio management turned whistleblower. ${ }^{8}$

The consequences of research fraud on human health and clinical practice can be huge. The damage to global vaccination coverage caused by the fraudulent and discredited research by Andrew Wakefield published 16 years ago and finally formally retracted by the Lancet in 2010 has been incalculable. ${ }^{9}$ Yet he lives a free man in Texas, raking in money from various support groups. Fraudulent studies on pain research by the anaesthetist Scott Reuben influenced "evidence based" practice for years, with inestimable harm to patients. He was sentenced to six months' imprisonment, ${ }^{10}$ but criminal proceedings after serious research fraud are relatively rare. It is usually dealt with at an institutional level by measures such as retraction of the work, termination of contracts, and academic shaming.

\section{No adequate redress}

Many opine that this is fair, given that research fraud may be difficult to differentiate from incompetence, errors, bias, and misunderstanding. ${ }^{11}$ However, evidence suggests that deliberate fraud is prevalent. Data manipulation related to drug industry research is often dealt with through massive fines and marketing restrictions, ${ }^{12}$ but the code of conduct for investigating and tackling flagrant research fraud in academic settings is much less clear.

In most instances institutions and academic bodies do not follow up on alleged or proved wrongdoing with criminal proceedings. This may relate to the difficulty in establishing malfeasance beyond doubt; in other cases it may relate to concerns of reputational risk and consequences for the institution. There may also be the consideration of avoiding prolonged and expensive investigations. A recent assessment of 17 cases of misconduct reported by the US Office of Research Integrity for 2000-05 found that each investigation cost between $\$ 116000$ and $\$ 2 \mathrm{~m} .{ }^{13}$

Current measures are not enough. Although many perpetrators of research fraud never return to academic life; others may claw their way back to active research. Even Hwang Woo-suk, ${ }^{5}$ who was forced to resign as professor at Seoul National University after his landmark papers on stem cell research were found to be fraudulent, has been able to return to public and scientific life. He has written more than 100 scientific publications since his fall from grace in 2006, 40 in the past two years alone.

Notwithstanding the importance of preventive measures, currently research fraud offers relatively little risk for potentially great rewards, ${ }^{14}$ and the process for detecting research fraud is also too dependent on chance detection or whistleblowers. While medical journals and university research integrity bodies continue to tighten up regular processes for oversight and 
preventive failsafe mechanisms, it is important to treat research fraud no differently from financial and healthcare fraud. Global healthcare fraud has been shown to account for 3-8\% of an estimated $£ 2$ trillion in total healthcare costs, ${ }^{15}$ and although the potential costs of health research fraud are not known, the human, social, and economic costs are likely considerable.

I can accept that there is a gradient of research misconduct. But in cases where deliberate research fraud is proved after thorough investigation, additional deterrence through punitive measures such as criminal proceedings should be added to the repertoire of measures available. Research misconduct is not just related to instances of harmless manipulation of molecules and chemicals in laboratory settings: its consequences on health and society can be huge. It is time to regard such behaviour in the same category as criminal fraud and deal with it accordingly.

\section{No-Julian Crane}

Trust lies at the heart of any collective human enterprise. The current avalanche of contractual and legally enforced accountability designed to replace it suggests that we have a crisis of trust, or so claimed the philosopher Onora O'Neill at the start of her 2002 Reith lectures. ${ }^{16}$ Trying to enforce accountability by criminalising research fraud would not improve trust-it would undermine it. No matter what criminal sanctions are enacted there will always remain considerable opportunity for deception by researchers that is much better prevented by transparency in an appropriate institutional environment.

Research fraud is perceived to be widespread and harmful, and institutions are perceived to be unable or unwilling to police it. Terminology is important, and the word "research" may euphemistically soften the word "fraud." " One definition of research misconduct is "behaviour by a researcher, intentional or not, that falls short of good ethical and scientific standards." 18 But the former editor of The BMJ Richard Smith recently defined research misconduct as "the gentlemanly phrase for scientific fraud." 19

Few researchers (and many of the world's great discoverers) at some time in their career would not have fallen foul of the first definition. So are we all fraudsters, albeit gentlemanly ones? Before we try to codify laws under which researchers may be investigated, arrested, and criminally charged we need to clarify what we mean by misconduct and fraud.

\section{Not such a big problem}

Smith says that research misconduct is "terrifyingly common." Published retractions as a surrogate for misconduct have been tracked since the 1970s and have recently been systematically reviewed. ${ }^{1}$ Most retractions $(67.4 \%)$ have resulted from proved or suspected misconduct. PubMed has indexed more than 25 million abstracts since the 1940s, and the first retraction was published in 1977, though there are likely to have been articles that should have been retracted before the 1970s. There have been 2047 published retractions since 1977. ${ }^{1}$ If we assume that $67 \%$, or 1371, are for misconduct then one in every 18234 published abstracts is subsequently retracted because of real or suspected misconduct. Rather than "terrifyingly common," in a world where bankers, journalists, politicians, parliamentarians, police officers, and security agencies have been called to account for misconduct, the rate for health scientists seems refreshingly small.

But the retraction rate has increased 10-fold since the 1970s. Why? Misconduct is easier to track with electronic publication, but pressure has also increased on researchers to publish quickly and with as much impact as possible to ensure ongoing funding and academic promotion. And we now have an index for an individual's research productivity and impact that does not escape employers and promotion committees and national research review exercises. ${ }^{20}$

In 35 years of attending international conferences I have seen their form change from reasonable attempts to exchange ideas to glitzy marketing and revenue generating exercises dominated by industry. "Celebrity" speakers jet in, present overviews without discussion in large plenary sessions, and jet out, while presentations of new science or the substance of research shrinks, with less opportunity for discussion. Form seems to have become increasingly important at the expense of substance. It's hardly surprising then that a small proportion of researchers cheat on the substance to obtain the form.

\section{Criminalisation will not help}

Biomedical research misconduct of course causes harm. But would inviting the police to investigate more satisfactorily uncover misconduct or prevent harm? It seems unlikely. Consider the now infamous retracted paper on the MMR (measles, mumps, and rubella) vaccine. ${ }^{21}$ It is the most cited case of misconduct (758 citations at June 2012) and centred on a case series of just 12 children. ${ }^{1}$ The misconduct—consisting of incorrect case definitions and laboratory results, lack of appropriate ethical review, and serious conflicts of interestwas exposed by a journalist. ${ }^{22}$ Would the threat of criminal proceedings have deterred publication? It seems unlikely: the approach of discrediting one vaccine to promote a potentially lucrative alternative suggests a mindset far beyond the concerns of the threat of prosecution. And who exactly would have called the cops and when?

At the other end of the scale are Yoshitaka Fujii's 172 fraudulent publications (of a total of 249) over 19 years, many with fabricated data on postoperative nausea and vomiting. ${ }^{23}$ The only motive here seems to have been publish or perish. His coauthors were unaware of the fraud; indeed some were unaware they were coauthors. This is really the heart of this issue. It behoves everyone involved in research, from university vice chancellors or institute chief executives to journal editors, coauthors, and research staff, to be aware of what is or what is not going on around them, with appropriate pathways for concerns to be aired and appropriately investigated.

O'Neill argues that growing bureaucratised accountability hampers rather than promotes trust and that a more intelligent approach is required based on reliable and verifiable information. In hindsight, the sources of funding and case histories of the 12 children could easily have been verified in the MMR paper; there were 13 authors to do it. ${ }^{21}$ It is surely not beyond the expertise of research organisations and their staff to reduce opportunities for misconduct, encourage open and verifiable information on which trust can be built, investigate appropriately, and correct misconduct in almost all its flavours. The UK Research Integrity Office (www.ukrio.org) and the US Office of Research Integrity (http://ori.hhs.gov) help researchers and organisations to deal with misconduct.

What happens when the police and the judiciary do get involved? Ask the Italian seismologists convicted of manslaughter and given six year jail terms and hefty fines for failing to predict an earthquake. ${ }^{24}$ Here the definitions of misconduct or fraud are irrelevant: they didn't commit any. Criminalising research misconduct is a sad, bad, even mad idea that will only undermine 
the trust that is an essential component of research and requires good governance not criminal investigators.

Competing interests: Both authors have read and understood BMJ policy on declaration of interests and have no relevant interests to declare.

Provenance and peer review: Commissioned; not externally peer reviewed.

1 Fang FC, Steen RG, Casadevall A. Misconduct accounts for the majority of retracted scientific publications. [Erratum appears in Proc Natl Acad Sci U S A 2013:110:1137] scientific publications . [Erratum appears in Proc
Proc Natl Acad Sci U S A 2012;109:17028-33.

2 Grieneisen ML, Zhang M. A comprehensive survey of retracted articles from the scholarly literature. PLoS One 2012;7:e44118.

3 Sarwar U, Nicolaou M. Fraud and deceit in medical research. J Res Med Sci 2012;17:1077-81.

$4 \quad$ Fanelli D. How many scientists fabricate and falsify research? A systematic review and meta-analysis of survey data. PLoS One 2009;4:e5738.

5 Glenn D. In South Korea, ethics questions prompt a stem-cell pioneer to resign a top post. Chron High Educ 2005;52:35.

6 Obokata H, Wakayama T, Sasai Y, Kojima K, Vacanti MP, Niwa H. Retraction: stimulus-triggered fate conversion of somatic cells into pluripotency. Nature 2014;511:112.

7 Roehr B. GlaxoSmithKline is fined record \$3bn in US. BMJ 2012;345:e4568.

8 Kay M. Indian generics manufacturer Ranbaxy agrees to pay $\$ 500 \mathrm{~m}$ to settle US fraud and drug safety charges. BMJ 2013;346:f3536.

9 Maisonneuve H, Floret D. [Wakefield's affair: 12 years of uncertainty whereas no link between autism and MMR vaccine has been proved]. Presse Med 2012;41:827-34.

10 Maslen G. Scientists sent to prison for fraudulent conduct. University World News 2013 Apr 25. www.universityworldnews.com/article.php?story=20130425143432184.
11 Markey ML. Scientific misconduct in research. J Health Life Sci Law 2007;63:65-97.

12 Moral decay at GSK reaps record $\$ 3$ bn fine. Lancet 2012;380:2.

13 Gammon E, Franzini L. Research misconduct oversight: defining case costs. $J$ Health Care Finance 2013;40:75-99.

14 Fenning TM. Fraud offers big rewards for relatively little risk. Nature 2004;427:393.

15 Gee J, Button M. The financial cost of health care fraud 2014. Center for Counterfraud Studies, 2014. https://fullfact.org/wp-content/uploads/2014/03/The-Financial-Cost-ofHealthcare-Fraud-Report-2014-11.3.14a.pdf.

16 O'Neill O. A question of trust (BBC Reith Lectures). 2002. www.bbc.co.uk/radio4/reith2002/

17 Call the cops. Nature 2013;504:7.

18 Misconduct in biomedical research: final consensus statement. In: Nimmo W, ed. Joint consensus conference on misconduct in biomedical research. Proc $R$ Coll Physicians Edinb 2000;30(suppl 7):2.

19 Smith R. Should scientific fraud be a criminal offence? BMJ blogs, 3 December 2013. http://blogs.bmj.com/bmj/2013/12/09/richard-smith-should-scientific-fraud-be-a-criminaloffence/.

20 Hirsch GS. An index to quantify an individual's scientific research output. Proc Natl Acad Sci 2005;102:16569-72.

21 Wakefield AJ, Murch SH, Anthony A, Linnell J, Casson DM, Malik M, et al. lleal-lymphoid-nodular hyperplasia, non-specific colitis, and pervasive developmental disorder in children. Lancet 1998;351:637-41.

22 Deer B. Solved-the riddle of MMR. http://briandeer.com/solved/solved.htm.

23 Jolley D. Fujii, anaesthesia and research fraud. 2012. http://gasexchange.com/articles/ fujii-anesthesia-research-fraud/\#note-1364-4.

24 Nosengo N. Italian court finds seismologists guilty of manslaughter. Nature 2012 Oct 22 . doi:10.1038/nature.2012.11640.

Cite this as: BMJ 2014;349:g4532

(c) BMJ Publishing Group Ltd 2014 